\title{
Effect of harvesting time and storage on essential oil and PEME content of Pandanus fascicularis
}

\author{
Noohi Nasim ${ }^{1}$, Jay Krishna Behera ${ }^{2}$, I. Sriram Sandeep ${ }^{1}$, Basudeba Kar $^{1}$, V.V. Ramarao ${ }^{2}$, Ramesh Srivastava ${ }^{2}$, \\ Sanghamitra Nayak ${ }^{1}$, Sujata Mohanty ${ }^{1 *}$ \\ ${ }^{1}$ Centre of Biotechnology, Siksha O Anusandhan University, Bhubaneswar - 751003, India. \\ ${ }^{2}$ Fragrances and Flavour Development Centre, Kannauj, MSME, Govt. Of India, India.
}

\author{
ARTICLE INFO \\ Article history: \\ Received on: 23/06/2017 \\ Accepted on: 08/09/2017 \\ Available online: $30 / 10 / 2017$ \\ Key words: \\ Pandanus fascicularis, \\ essential oil, harvesting time, \\ PEME content.
}

\begin{abstract}
Pandanus fascicularis L. commonly known as kewda is an important aromatic and medicinal plant belonging to the family Pandanaceae. The kewda oil has a characteristic aroma mainly due to the presence of phenyl ethyl methyl ether (PEME). In addition, terpinen-4-ol, $\alpha$-terpineol and p-cymene also contribute to the fragrance of the oil. Owing to its aroma, kewda oil possesses great demand in flavour and fragrance industry. Due to high volatile nature of PEME, the flower harvesting and storage procedures play an important role in quality and yield of oil. Keeping this in view, the present experiment was carried out where the essential oil was isolated from freshly plucked flowers and cold stored kewda flowers (stored at $4{ }^{\circ} \mathrm{C}$ ) at $0 \mathrm{hr}, 3 \mathrm{hrs}$ and $6 \mathrm{hrs}$ respectively. The essential oil was then subjected to GC and GC-MS analysis. The results revealed that the PEME percentage decreased in fresh and stored flowers from $0 \mathrm{hr}(82 \%)$ to $3 \mathrm{hrs}(77 \%, 72 \%)$ and $6 \mathrm{hrs}(46 \%, 68 \%)$. PEME and terpinen-4-ol content was higher in cold stored flowers than fresh flowers at both the time intervals. Thus, harvesting time and storage of flower play a crucial role in kewda oil yield and quality.
\end{abstract}

\section{INTRODUCTION}

Pandanus fascicularis is one of the densely populated plant species in coastal regions of India. It is seen in the states of Odisha, Andhra Pradesh, Kerala, Tamil Nadu, West Bengal, some regions of Uttar Pradesh and Gujarat (Charterjee and Pakrashi, 2001). The plant is also well distributed in South-East Asia and extended up to Papua New Guinea, North Australia and Pacific islands (Panda et al., 2012). Pandanus is a dioecious plant and is much valued for the male inflorescence, which emits fragrance. The female inflorescence does not possess the fragrance and later develop into fruit. P. Fascicularis have wide range of medicinal properties (Andriani et al., 2015). The leaves are used for treating boils, cold/flu, hepatitis and cancer (Meilleur et al., 1997). The extract of plant is known for its diuretic and anti-spasmodic properties (Kirtikar et al., 1991).

\footnotetext{
* Corresponding Author

E-mail: sujatamohantyils@gmail.com; Tel: +91 9238686246,
}

The fruits and male flowers are used for treating skin and heart related infections (Adkar and Bhaskar, 2014). Leaf extracts containing tablets are given for pain and inflammation in traditional medicine preparations (Panda et al., 2009). Besides, the leaves of Pandanus are tough and have spines thus employed as fence for crops to protect from cattle. They are also used for making mats, ropes, baskets, purses etc. The trunks of aged plants are used in thatched house construction (Little and Skolmen, 1989). Pandanus is highly valued for the three products that include kewda oil, kewda attar and kewda water. The kewda oil has great demand in perfumery industry and stands at Rs, 3,00,000/kg (Panda et al., 2012). It is used for treating headache, rheumatoid arthritis, spasms and leprosy (Adkar and Bhaskar, 2014). The attar is mostly used as flavouring purposes in sweets, soft drinks and dishes. The major component of kewda oil is phenyl ethyl methyl ether (PEME) and is responsible for the characteristic aroma (Raina et al., 2004). Some other components like terpinen-4-ol, $\alpha$-terpineol and p-cymene also contribute to the fragrance. 
Most of the kewda growing regions are found in the coastal zones of India and are available in wild areas. The harvesting time and extraction of essential oil from kewda flowers largely affect the essential oil yield and quality due to the high volatile nature of PEME. The flowers are plucked in early hours and are immediately processed for oil extraction. Massive quantity of flowers has to be hydro-distilled during this period and it is quite challenging task in places where the distillation equipment is not readily available. In those situations, the flowers have to be transported to the nearby places. The time taken for transportation leads to decrease in the quality and aroma of kewda oil. Thus, price of the oil also decreases. Most of the kewda farmers are not aware of this fact and many times, they face huge loss due to the above problem. Besides, during flowering season though huge flower collection occurs but extraction is not possible due to less number of extraction units. Reports on extraction of essential oil from cold stored flowers for minimizing loss of oil yield and quality are very scanty (Kumar et al., 2013; Sharma and Kumar, 2015). Until now, no information is available on the essential oil isolation at different time intervals in cold stored and freshly plucked kewda flowers. Further, the transportation of flowers without the hampering the PEME content would be a great benefit to kewda industry. Thus, the present study was undertaken to investigate the essential oil composition and yield of freshly plucked and cold stored kewda flowers at different time intervals.

\section{MATERIALS AND METHODS}

\section{Plant material collection}

Kewda flower samples were collected from Rushikulya River Belt 19²3'11.77'N 85¹'36.53'E (Ganjam District, Odisha, India) during August-September. The flowers were collected early morning (6 A.M) by the help of local experts at different time intervals (0hr, 3hrs and 6hrs). Some flowers are stored at $4{ }^{\circ} \mathrm{C}$ for $3 \mathrm{hrs}$ and 6hrsto evaluate the essential oil composition and PEME content at different time intervals. A minimum of ten flowers at each time point were subjected to hydro-distillation. The experiment was carried out in triplicate both from field and from stored samples.

\section{Essential oil extraction}

For essential oil extraction all the collected flower samples were carefully transported to the distillation units. The green spathe of inflorescence was removed completely manually to improve the essential oil yield. The oil extraction was carried out by Clevenger's apparatus from all the flowers. The flowers are chopped in to small pieces and $1000 \mathrm{~g}$ of flowers are placed in the flask to which $3000 \mathrm{ml}$ of distilled water is added. The flask is allowed to heat up to $60-70{ }^{\circ} \mathrm{C}$ for $3-4 \mathrm{hrs}$ and the obtained essential oil is stored in glass vials at $4{ }^{\circ} \mathrm{C}$.

\section{GC-MS analysis}

The essential oils were analysed by GC-MS coupled with SQ8 Mass Detector; ionization voltage $70 \mathrm{eV}$; electron multiplier energy $1385 \mathrm{~V}$. The GC analysis was carried out with a Perkin-Elmer Clarus 580 gas chromatograph fitted with an Elite-5 MS capillary column $(30 \mathrm{~m}$ x $0.25 \mathrm{~mm}$ i.e.; $0.25 \mu \mathrm{m}$ film thickness). Helium was the carrier gas $(1 \mathrm{ml} / \mathrm{min})$. Injector temperature was set at $250{ }^{\circ} \mathrm{C}$ with source temperature $180^{\circ} \mathrm{C}$. The column temperature was initially kept at $60^{\circ} \mathrm{C}$ and then gradually increased to $220^{\circ} \mathrm{C}$ at $3{ }^{\circ} \mathrm{C} / \mathrm{min}$ with $7 \mathrm{~min}$ hold at $220^{\circ} \mathrm{C}$. $0.1 \mu \mathrm{l}$ of neat oil was injected into the system. Further identification was made by comparison of their mass spectra with those stored in NIST libraries.

\section{RESULTS}

\section{Essential oil yield}

Extraction of flower essential oil was done from field and cold stored samples. Plucking of flower was done at 6A.M and taken as control. Some flowers were kept in $4{ }^{\circ} \mathrm{C}$. After $3 \mathrm{hrs}$ and 6 hrs, extraction of essential oil was done from field and cold stored samples. Variation in essential oil yield was shown in (Figure1). The oil yield in control sample was $0.052 \%$. In the cold stored flowers, the essential oil at $3 \mathrm{hrs}$ was $0.036 \%$ and at $6 \mathrm{hrs}$, it further declined to $0.016 \%$. In the field samples, the essential oil yield percentage was $0.028 \%$ ( $3 \mathrm{hrs}$ ) and $0.017 \%$ (6 hrs). The percentage of oil was higher in cold stored flowers at $3 \mathrm{hrs}$ time period as compared to freshly plucked flowers.

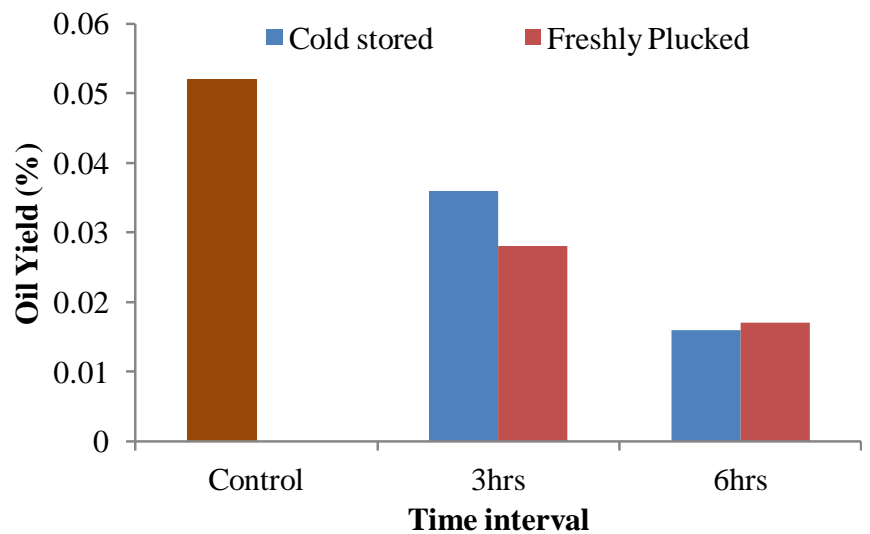

Fig. 1: Essential oil yield percentage at different time intervals in freshly plucked and cold stored flowers.

\section{Composition of essential oil}

The kewda samples were subjected to GC/MS analysis and 31 compounds were identified. The GC-MS chromatogram is presented in (Figure 2). PEME was the major constituent of all the samples followed by terpinen-4-ol, alpha-terpineol and gammaterpinene. The percentage of PEME ranged from 67.9 to $71.93 \%$ in cold stored flowers while it ranged from 46.79 to $77.66 \%$ in freshly plucked flowers at different time intervals (Figure 3). PEME $(81.85 \%)$, terpinen-4-ol (7.9\%), gamma-terpinene $(1.82 \%)$, sabinene $(0.99 \%)$ p-cymene $(0.66 \%)$ together accounted for $93.22 \%$ in the control. The other constituents which were present include myrcene, phenylethyl alcohol, 1,8-cineole, alpha-thujene, trans-sabinol, cis-p-menth-2-en-1-ol and cis-piperitol. 


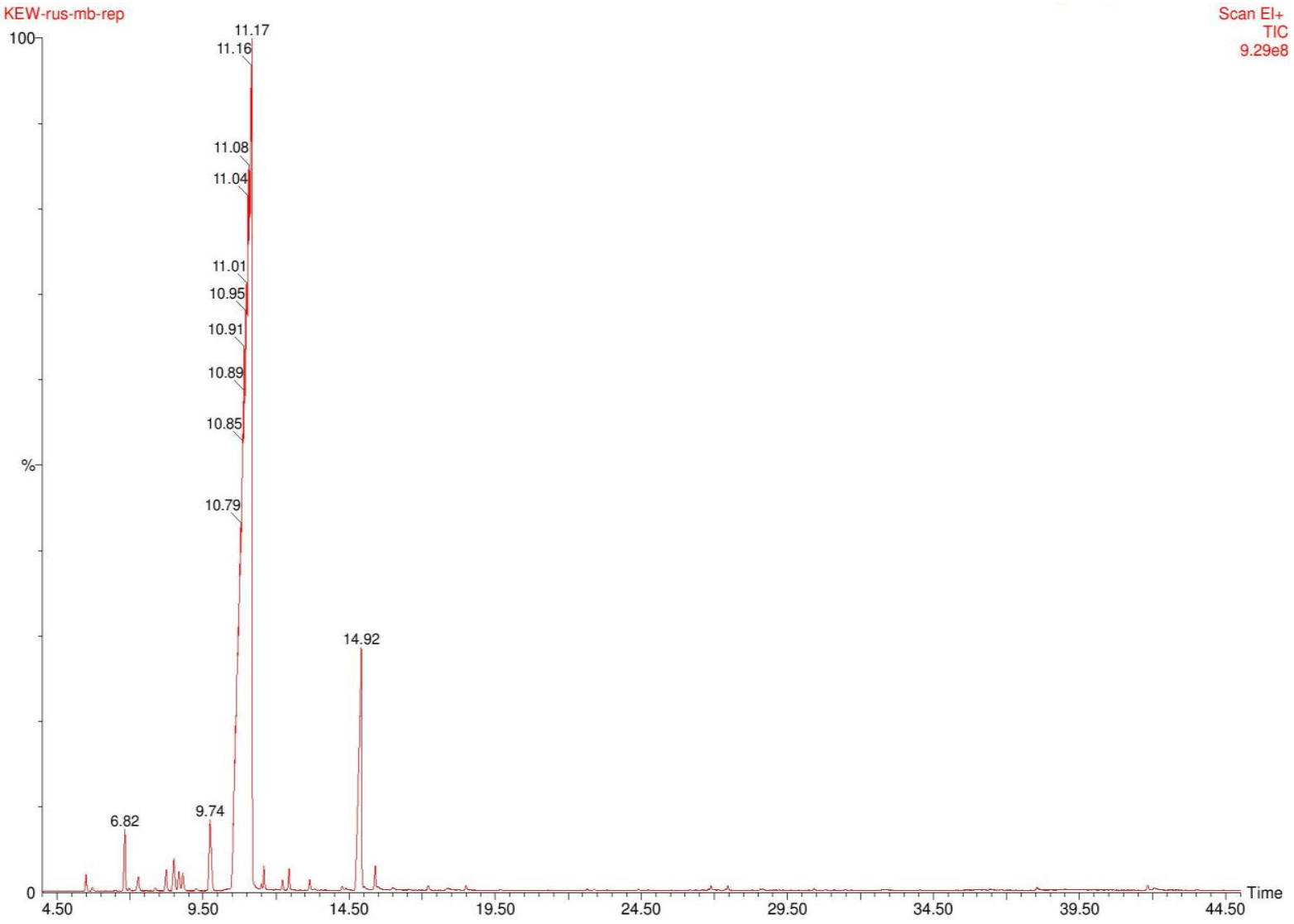

Fig. 2: GC-MS Chromatogram of kewda essential oil.
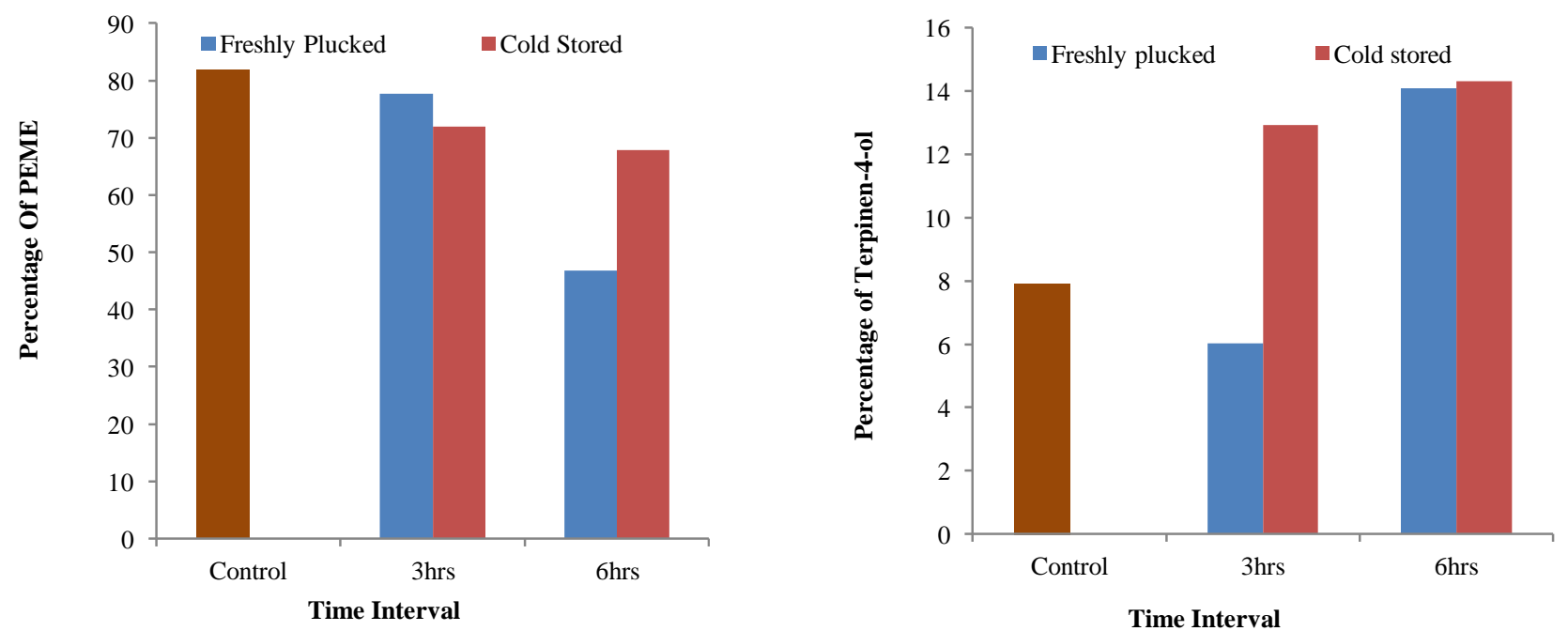

Fig. 3: Percentage of PEME and terpinen-4-ol in freshly plucked and cold stored flowers.

\section{Comparison of GC/MS profile between cold stored and freshly plucked flowers}

GC/MS profile of the samples illustrated the presence of 31 different chemotypes of which 11 chemotypes were present in all the oil samples. The total percentage of oil components decreased to $90.05 \%$ at $3 \mathrm{hrs}$ and further decreased to $88.31 \%$ at $6 \mathrm{hrs}$ in cold stored flowers. The decrease in the percentage is resulted due to the decrease in PEME content (Table 1).
The PEME percentage was $71.93 \%$ ( $3 \mathrm{hrs)} \mathrm{and} 67.9 \%$ (6 hrs) in cold stored flowers. The PEME percentage in freshly plucked flowers was $77.66 \%$ (3 hrs). In case of freshly plucked flowers, the total constituent percentage declined from $88.99 \%$ to $73.01 \%$.

Greater decrease PEME content was noticed at $6 \mathrm{hrs}$ of oil extraction. The PEME content was $77.66 \%$ ( $3 \mathrm{hrs}$ ) and 46.79 (6 hrs) respectively. 
Table 1: GC/MS profile of kewda oil samples at different periods.

\begin{tabular}{|c|c|c|c|c|c|c|c|c|}
\hline \multirow{3}{*}{ S. No. } & \multirow{3}{*}{ Compound Name } & \multirow{3}{*}{ Control } & \multirow{2}{*}{\multicolumn{2}{|c|}{$\begin{array}{c}\text { Cold } \begin{array}{c}\text { Stored } \\
\text { Flowers }\end{array} \\
\end{array}$}} & \multirow{2}{*}{\multicolumn{2}{|c|}{$\begin{array}{c}\text { Freshly Plucked } \\
\text { Flowers }\end{array}$}} & \multirow{3}{*}{$\begin{array}{c}\text { Mol } \\
\text { Formula }\end{array}$} & \multirow{3}{*}{$\begin{array}{r}\text { Mol } \\
\text { Weigh }\end{array}$} \\
\hline & & & & & & & & \\
\hline & & & $3 \mathrm{hrs}$ & $6 \mathrm{hrs}$ & 3 hrs & $6 \mathrm{hrs}$ & & \\
\hline 1 & PEME & 81.856 & 71.93 & 67.9 & 77.661 & 46.792 & $\mathrm{C} 9 \mathrm{H} 12 \mathrm{O}$ & 136 \\
\hline 2 & terpinen-4-ol & 7.9 & 12.918 & 14.3 & 6.021 & 14.077 & $\mathrm{C} 10 \mathrm{H} 18 \mathrm{O}$ & 154 \\
\hline 3 & gamma-terpinene & 1.826 & 1.03 & 1.24 & 1.383 & 3.112 & $\mathrm{C} 10 \mathrm{H} 16$ & 136 \\
\hline 4 & sabinene & 0.994 & 0.423 & 0.343 & 0.478 & 0.787 & $\mathrm{C} 10 \mathrm{H} 16$ & 136 \\
\hline 5 & p-cymene & 0.665 & 0.139 & 0.278 & 0.249 & 0.378 & $\mathrm{C} 10 \mathrm{H} 14$ & 134 \\
\hline 6 & alpha-terpinene & 0.414 & 0.415 & 0.315 & 0.467 & 1.335 & $\mathrm{C} 10 \mathrm{H} 16$ & 136 \\
\hline 7 & alpha-terpineol & 0.394 & 1.26 & 2.132 & 1.036 & 1.932 & $\mathrm{C} 10 \mathrm{H} 18 \mathrm{O}$ & 154 \\
\hline 8 & trans-p-menth-2-en-1-ol & 0.322 & 0.341 & - & 0.221 & - & $\mathrm{C} 10 \mathrm{H} 18 \mathrm{O}$ & 154 \\
\hline 9 & d-limonene & 0.305 & 0.156 & 0.211 & 0.177 & 0.283 & $\mathrm{C} 10 \mathrm{H} 16$ & 136 \\
\hline 10 & myrcene & 0.284 & - & 0.146 & - & 0.246 & $\mathrm{C} 10 \mathrm{H} 16$ & 136 \\
\hline 11 & phenylethyl alcohol & 0.265 & - & 0.111 & - & 0.211 & $\mathrm{C} 8 \mathrm{H} 10 \mathrm{O}$ & 122 \\
\hline 12 & 1,8 -cineole & 0.256 & 0.214 & 0.207 & 0.184 & 0.257 & $\mathrm{C} 10 \mathrm{H} 18 \mathrm{O}$ & 154 \\
\hline 13 & alpha-thujene & 0.253 & 0.34 & 0.191 & 0.21 & 0.594 & $\mathrm{C} 10 \mathrm{H} 16$ & 136 \\
\hline 14 & trans-sabinol & 0.182 & - & - & - & - & $\mathrm{C} 10 \mathrm{H} 16 \mathrm{O}$ & 152 \\
\hline 15 & cis-p-menth-2-en-1-ol & 0.142 & 0.115 & 0.158 & 0.118 & 0.58 & $\mathrm{C} 10 \mathrm{H} 18 \mathrm{O}$ & 154 \\
\hline 16 & cis-piperitol & 0.109 & - & - & - & - & $\mathrm{C} 10 \mathrm{H} 18 \mathrm{O}$ & 154 \\
\hline 17 & camphor & - & 0.208 & 0.135 & 0.158 & 0.435 & $\mathrm{C} 10 \mathrm{H} 16 \mathrm{O}$ & 152 \\
\hline 18 & linalool propionate & - & 0.198 & - & 0.247 & - & $\mathrm{C} 13 \mathrm{H} 22 \mathrm{O} 2$ & 210 \\
\hline 19 & phenylethylphenyl acetate & - & 0.184 & - & 0.202 & - & $\mathrm{C} 16 \mathrm{H} 16 \mathrm{O} 2$ & 240 \\
\hline 20 & beta-pinene & - & 0.179 & - & 0.182 & - & $\mathrm{C} 10 \mathrm{H} 16$ & 136 \\
\hline 21 & piperitone & - & - & 0.176 & - & 0.356 & $\mathrm{C} 10 \mathrm{H} 16 \mathrm{O}$ & 152 \\
\hline 22 & trans-piperitol & - & - & 0.137 & - & 0.237 & $\mathrm{C} 10 \mathrm{H} 18 \mathrm{O}$ & 154 \\
\hline 23 & caryophyllene oxide & - & - & 0.121 & - & 0.121 & $\mathrm{C} 15 \mathrm{H} 24 \mathrm{O}$ & 220 \\
\hline 24 & alpha-pinene & - & - & 0.109 & - & 0.209 & $\mathrm{C} 10 \mathrm{H} 16$ & 136 \\
\hline 25 & linalool & - & - & 0.104 & - & 0.172 & $\mathrm{C} 10 \mathrm{H} 18 \mathrm{O}$ & 154 \\
\hline 26 & gamma-cadinene & - & - & - & - & 0.198 & $\mathrm{C} 15 \mathrm{H} 24$ & 204 \\
\hline 27 & alpha-cadinene & - & - & - & - & 0.183 & $\mathrm{C} 15 \mathrm{H} 24$ & 204 \\
\hline 28 & germacrene-B & - & - & - & - & 0.164 & $\mathrm{C} 15 \mathrm{H} 24$ & 204 \\
\hline 29 & nerolidol & - & - & - & - & 0.142 & $\mathrm{C} 15 \mathrm{H} 26 \mathrm{O}$ & 222 \\
\hline 30 & alpha-amorphene & - & - & - & - & 0.109 & $\mathrm{C} 15 \mathrm{H} 24$ & 204 \\
\hline \multirow[t]{2}{*}{31} & aromadendrene & - & - & - & - & 0.105 & $\mathrm{C} 15 \mathrm{H} 24$ & 204 \\
\hline & TOTAL (\%) & 96.167 & 90.05 & 88.314 & 88.994 & 73.015 & & \\
\hline
\end{tabular}

The second major constituent terpinen-4-ol was $12.91 \%$ (3hrs) and $14.3 \%$ (6hrs) in cold stored flowers while it was $6.02 \%$ (3hrs) and $14.07 \%$ (6hrs) in freshly plucked flowers. Gamma terpinene was higher in fresh plucked flowers at 6hrs time period. Myrcene and phenylethyl alcohol were absent at $3 \mathrm{hrs}$ in both freshly plucked and stored flowers. Few other compounds were limited to a particular time period such as linalool propionate, phenylethylphenyl acetate and beta-pinene which were present only in 3 hrs samples and some other constituent's piperitone, trans-piperitol, caryophyllene oxide, alpha-pinene and linalool were present only in 6hrs samples. The compound cis-piperitol was only identified in control samples. PEME (46.79\%) of freshly plucked samples at $6 \mathrm{hrs}$ time period was the lowest.

\section{DISCUSSION}

In this study, the effect of harvesting time on quality and yield of kewda essential oil were analyzed by collecting flowers at different time intervals. PEME is major constituent of kewda essential oil and is responsible for the aroma it possesses. The results suggest that the PEME content is greatly affected by harvesting time as the diminished PEME content was clearly noticed in the oil isolated at $6 \mathrm{hrs}$. This can be correlated with the fact that aromatic compounds diffuse when the temperature is high and PEME is highly volatile in nature. High temperatures resulted in decrease in the essential oil content in peppermint (Blanco et al., 2002) and bay leaf (Sekeroglu et al., 2007). Early distillation increased the oil yield in rose flowers (Baydar, 2006). Thus, storage of flower samples without affecting the essential oil yield and quality will enhance their market potential in plants like kewda. It was noticed in the present report that the content of PEME was maintained when the flowers are stored at $4{ }^{\circ} \mathrm{C}$ up to 6 hrs time period. Thus, transport of kewda flowers from different cultivated and wild regions could be possible to the extraction unit without change in quantity and quality of its essential oil.

Harvesting time and storage of rose flowers affect its oil yield and quality (Sharma and Kumar, 2015; Baydar et al., 2008). According to Kumar et al, (2013) optimal results in terms of the oil content and components were obtained from the rose flowers distilled immediately after the harvest compared to the flowers stored at $25{ }^{\circ} \mathrm{C}$ and $18{ }^{\circ} \mathrm{C}$. However, at $4{ }^{\circ} \mathrm{C}$ rose flowers can be stored for $16 \mathrm{hrs}$ without much effect in oil content and composition. Our result was in close agreement with it. The results obtained in this study showed that the PEME content was the lowest from the samples collected at 6hrs (in field) but the PEME content was maintained in cold stored flowers (67.9\%). Hence, kewda flowers could be stored up to 6 hours at $4{ }^{\circ} \mathrm{C}$ without much distressing its essential oil yield and PEME content. 


\section{CONCLUSION}

Kewda is an economically important plant due to its high priced flower essential oil. Quality of kewda oil by means of PEME percentage is the determinant of its market price. Time gap between collections of flowers from field and extraction of oil further stringent the rise and fall of PEME content and indirectly affect the quality of oil. Thus, our report bears immense potential towards solving the above problem and to provide a way out towards storage of kewda flowers without change in its oil quality and quantity. It also could be helpful to minimise great loss to the kewda growers.

\section{ACKNOWLEDGEMENT}

Authors are thankful to Dr S.C. Si, Dean and Mr. M. R Nayak, President, SOA University for providing all facilities.

Financial support and sponsorship: Financial support from Department of Biotechnology, Govt. Of India is deeply acknowledged.

Conflict of Interests: There are no conflicts of interest.

\section{REFERENCES}

Adkar PP, Bhaskar VH. Pandanus odorotissimu s(Kewda): a review on ethnopharmacology, phytochemistry, and nutritional aspects. Adv Pharmacol Sci, 2014; 2014: 1-19.

Andriani Y, Ramli NM, Syamsumir DF, Kassim MN, Jaafar J, Aziz NA, Marlina L, Musa NS, Mohamad H. Phytochemical analysis, antioxidant, antibacterial and cytotoxicity properties of keys and cores part of Pandanus tectorius fruits. Arab J Chem, 2015 doi: http://dx.doi.org/10.1016/j.arabjc.2015.11.003.

Baydar H. Oil-bearing rose (Rosa damascena Mill.) cultivation and rose oil industry in Turkey. Euro Cosmetics, 2006; 14:13-17.

Baydar H, Schulz H, Kruger H, Erbas S, Kineci S. Influences of fermentation time, hydro-distillation time and fractions on essential oil composition of damask rose (Rosa damascena Mill.). J Essent oil Bear Pl, 2008; 11:224-232.

Blanco MCSG, Ming LC, Marques MOM, Bovi OA. Drying temperature effects in peppermint essential oil content and composition. Acta Hortic, 2002; 569:95-98.
Chatterjee A, Pakrashi SC. The Treatise on Indian medicinal plants. 2001, National Institute of Science communication (CSIR), New Delhi 6.

Kirtikar KR, Basu BD, Blatter E. Indian Medicinal Plants, Indian Book Center, New Delhi, India, 1991; 4:115-118.

Kumar R, Sharma S, Sood S, Agnihotri VK, Singh B. Effect of diurnal variability and storage conditions on essential oil content and quality of damask rose (Rosa damascena Mill.) flowers in north western Himalayas. Sci Hortic, 2013; 154:102-108.

Little EL, Skolmen RG. Common Forest Trees of Hawaii (Native and Introduced). 1989 Agricultural Handbook 679, USDA, Washington, DC, USA.

Meilleur BA, Maigret MB, Manshardt R. "Hala,Wauke in Hawai'i,” Bishop Museum Bull Anthropol, 1997; 7:1-55.

Panda K, Das AB, Panda BB. Genomics of Pandanus: A useful plant resource of coastal Odisha, India, 2012 Lambert Academic Publishing.

Panda KK, Das AB, Panda BB. Use and variation of Pandanus tectorius Parkinson (P. fascicularis Lam.) along the coastline of Orissa, India. Genet Resour Crop Evol, 2009; 56:629-637.

Raina VK, Kumar A, Srivastava SK, Syamsundar KV, Kahol AP. Essential oil composition of "kewda"(Pandanus odoratissimus) from India. Flavour Fragr J, 2004; 19:434-436.

Sekeroglu N, Ozguven M, Erden U. Effect of drying temperature on essential oil content of bay leaf (Laurus nobilis L.) harvested in different times. International Symposium on Medicinal and Nutraceutical Plants, 2007; 756:315-320.

Sharma S, Kumar R. Effect of temperature and storage duration of flowers on essential oil content and composition of damask rose (Rosa $\times$ damascena Mill.) under western Himalayas. J Appl Res Med Aromat Plants, 2015. doi: http://dx.doi.org/10.1016/j.jarmap.2015.10.001.

How to cite this article:

Nasim N, Behera JK, Sandeep IS, Kar B, Ramarao VV, Srivastava R, Nayak S, Mohanty S. Effect of harvesting time and storage on essential oil and PEME content of Pandanus fascicularis. J App Pharm Sci, 2017; 7 (10): 185-189. 